International Journal of Social Science And Human Research

ISSN(print): 2644-0679, ISSN(online): 2644-0695

Volume 04 Issue 07 July 2021

DOI: 10.47191/ijsshr/v4-i7-50, Impact factor-5.586

Page No: 1938-1948

\title{
Assets Recovery of Money Laundering Criminal Acts: A Study of Restoring Assets for Money Launching Criminal Acts Related in the Account of Overseas Bank
}

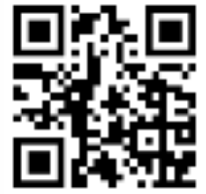

\author{
Sri Lestari Handayani ${ }^{1}$, Iwan Erar Joesoef ${ }^{2}$ \\ ${ }^{1,2}$ Faculty of Law, University of Pembangunan Nasional Veteran Jakarta, RS. Fatmawati Street, South Jakarta City, 12450
}

\begin{abstract}
This research was conducted to investigate the obstacles to asset recovery for the proceeds of money laundering deposited in offshore bank accounts, as mandated in Law Number 8 of 2010. The issues raised in this study are about the relationship between corruption and money laundering. As well as law enforcement in the monetary sector in Indonesia through the criminal approach and Asset Recovery in the Money Laundering case. Based on the research, it was found that the recovery of assets resulting from money laundering that was stored abroad experienced obstacles due to differences in legal concepts (money laundering and assets proceeds from money laundering). The research was conducted through juridical normative methods and data collection. It is concluded that the Asset Recovery approach is more of a deterrent effect for the perpetrators of corruption than punishment. To facilitate the withdrawal of money laundering funds abroad, a bilateral cooperation agreement between the Indonesian and recipient countries of money laundering assets is necessary.
\end{abstract}

KEYWORDS: Money Laundering, Corruption Crime, Asset Recovery.

\section{INTRODUCTION}

Many cases of money laundering are occurring in line with the increasing number of corruption cases. This condition is very detrimental to state finances because it is not easy to return assets resulting from money laundering crimes stored abroad. This is the background for the author to conduct research related to asset recovery on the proceeds of money laundering crimes held in foreign bank accounts. As mandated in Law No. 8 of 2010 concerning the Prevention and Eradication of the Crime of Money Laundering, this study was conducted to investigate the barriers to asset recovery from the proceeds of money laundering crimes deposited in foreign bank accounts. It is hoped that through this research, the relationship between corruption and money laundering is known, as well as law enforcement in the monetary sector in Indonesia through a criminal approach and Asset Recovery in the Money Laundering case.

The handling of money laundering crimes, as regulated in Law No. 15 of 2002 as amended by Law No. 25 of 2003, which was renewed by Law No. 8 of 2010, has shown the government's seriousness in transforming existing criminal law policies, which is called penal policies, to prevent as well as eradicating the crime of money laundering in Indonesia as optimally as possible, especially when compared to the provisions of the criminal law specified in the Criminal Code. Unfortunately, the existing laws and regulations still have gaps in the emergence of different interpretations. This results in inaccurate sanctions, a shift in the burden of proof, limited access to information, and even obstacles in returning assets from money laundering proceeds, which is called asset recovery. Penal policy, in general, is a form of rational arrangement or arrangement as an effort to control crime carried out by the community. ${ }^{1}$ Crime, according to Hoefnagels, is a relative understanding.

In essence, many meanings in social science come from common parlance ${ }^{2}$ Nevertheless, there are still many differences in understanding in society. The difference in interpreting the crime is due to the use of language that has not expressed a clear description of the crime. Likewise, with money laundering, certain parties think that money laundering is a natural thing, not an aberration, as long as it is carried out according to banking procedures to obscure the origin of the funds deposited.

According to Hans G. Nilsson (1996: ix), money laundering is a problem for the world community that has been an issue for almost two decades, especially in the Council of Europe. ${ }^{3}$ The Committee of Ministers in 1980 recommended to the international

\footnotetext{
${ }^{1}$ Muladi and Barda Nawawi Arief, Teori-Teori dan Kebijakan Hukum Pidana, (Bandung: Alumni, 2005), p. 157.

${ }^{2}$ Hoefnagels, G.P., The Other Side Of Criminology, (Kluwer- Deventer, Holand: 1972), p.72.

3 Hans G. Nilsson, Preface, Dalam Paolo Bernasconi (ED), Money Laundering and Banking Secrecy, General Report of Xi Vth International Congress of Comparative Law (Athens, 1996), p. ix.
} 
Assets Recovery of Money Laundering Criminal Acts: A Study of Restoring Assets for Money Launching Criminal Acts Related in the Account of Overseas Bank

community the dangers of democracy and the Rule of Law. In the recommendation, it is also stated that the transfer of proceeds of crime from one country to another and the increase in dirty money laundering activities through the economic system, both on a national and international scale, is a severe problem.

\section{PROBLEM FORMULATION}

1. What is the relationship between corruption and money laundering?

2. How are the law enforcement in the monetary sector in Indonesia through a criminal approach and Asset Recovery in the Money Laundering case?

\section{RESEARCH METHOD}

The type of research method chosen in this study is normative juridical research with research specifications as exploratory research where the research aims to examine and examine in more depth the principles and legal principles related to aspects of the function and role of state administrative law as well as criteria regarding pollution and environmental destruction according to the Act. This research will be carried out using a statute approach and a conceptual approach by the form and specifications of the research above. ${ }^{4}$

Sources of legal materials that have been collected will be processed and analyzed by carrying out a legal interpretation and evaluation of the legislation related to legal issues regarding the criteria for pollution and environmental destruction so that later conclusions can be drawn on legal norms regarding the role and effectiveness of enforcement - a law against environmental destruction and pollution in Indonesia.

\section{THEORETICAL FRAMEWORK}

In this study, the literature review used is the theory that forms the basis for the research. Besides that, the literature review is also carried out through national and international research journals as follows:

\section{Criminal Theory}

Sentencing is an essential part of criminal law, which can be interpreted as punishment. Sentencing is the culmination of the entire process of holding accountable someone guilty of a crime. Criminal theory, in general, is grouped into three major groups, which include:

1) Absolute Theory (Vergeldings Theorien)

This theory was introduced by Kant and Hegel, which is based on the idea that punishment is not practical, but punishment is an absolute requirement. In other words, the crime is an act of revenge (revenge). According to Immanuel Kant, in his book "The Philosophy of Law,"5 that:

"Crime is never carried out solely as a means to promote other goals/goods, both for the perpetrator concerned and for the community."

Muladi argues that the fundamental theory puts forward sanctions that in criminal law are imposed solely because people have committed a crime that is an absolute consequence of retaliation to people who commit crimes, where sanctions aim to satisfy the demands of justice. ${ }^{6}$

2) Relative Theory (Doel Theorien)

This theory is based on the opinion that crime is a tool to enforce order (law) in society. According to Muladi about this theory that:

"Punishment is not retaliation for the wrongdoing of the perpetrator but a means of achieving a worthwhile goal to protect the community towards the welfare of society. Sanctions are emphasized on the goal: to prevent people from committing crimes, so it is not aimed at absolute satisfaction of justice."7

3) The Theory of Combining (Verenigings Theorien).

This theory was introduced by Prins, Van Hammel, Van List, who argued that: ${ }^{8}$

a. The most crucial goal of crime is to eradicate crime as a symptom of society.

b. The science of criminal law and criminal legislation must pay attention to the results of anthropological and sociological studies.

c. Crime is one of the most effective ways that governments can use to combat crime.

4 Peter Mahmud Marzuki, Penelitian Hukum, Jakarta : Kencana, 2006, p. 32.

${ }^{5}$ Dalam Muladi dan Barda Nawawi, Teori dan Kebijakan Pidana. (Bandung: Alumni, 1992), p. 11

${ }^{6}$ Zainal Abidin Farid, Hukum Pidana 1, Sinar Grafika, Jakarta, 2007, p. 11.

7 Ibid. p. 11

8 Djoko Prakoso, Surat Dakwaan, Tuntutan Pidana dan Eksaminasi Perkara di Dalam Proses Pidana, Liberty, Yogyakarta, 1988, p. 47. 
Assets Recovery of Money Laundering Criminal Acts: A Study of Restoring Assets for Money Launching Criminal Acts Related in the Account of Overseas Bank

The combined theory is a theory that aims to improve humans or those who commit crimes, incredibly minor offenses. However, in certain offenses that are considered to damage social and community life, the deterrent nature or retaliation of the punishment cannot be avoided.

Based on the explanation related to the theory of punishment in the case of money laundering or money laundering, it can be concluded that the theory of punishment used is the Theory of Combining (Vereniging theorien).

\section{Asset Recovery Theory}

Asset recovery through criminal law has long been recognized and implemented in Indonesia, particularly concerning money laundering. When it is not necessary to prove in advance in the crime of money laundering, the legal action contains a civil element, but here it still has a large portion of the criminal aspect.

Regarding asset recovery, de Willebois (2012) calls it "civil remedies in corruption and asset recovery," which is more popularly known as "Non-Conviction Based Assets Forfeiture." In Indonesia, it has only reached the stage of a draft law initiated in 2012 named the Draft Law on the Confiscation of Assets for Criminal Actions. It seems that there is a need to be urged to become law immediately. So, the subject matter is still new in Indonesia.

Globally, concerns regarding the low rate of return on assets from the proceeds of corruption have been contained in Chapter V articles 51-59, United Nations Convention 2003 concerning corruption. Furthermore, more interestingly, Carr (2006: 29) stated that the decision was "The most radical section in the UN Convention...". He stated this assessment boldly. He also provided a new solution to asset recovery, which has always been a controversial theme and very difficult to implement.

\section{DISCUSSION}

\section{Relationship Between Corruption Crimes and Money Laundering}

The resultant direction of legal politics in the anti-money laundering regime can be seen with the enactment of Law No. 8 of 2010 concerning the Prevention and Eradication of Money Laundering as a grand design for the implementation as an effort to prevent and eradicate money laundering in Indonesia. The target of the issuance of Law No. 8 of 2010 is aimed at the target of a new direction of criminal law policy in the anti-money laundering regime, which includes: ${ }^{10}$

a. Maintain and maintain the stability and integrity of the national financial system against money laundering;

b. Prevent and eradicate a significant number of property-related crimes, as well as prevent the possibility of recurrence and expansion of these crimes;

c. Improving the coordination of law enforcement as an effort to prevent and eradicate the crime of money laundering;

d. Increase state revenue through confiscation and confiscation of proceeds of crime; and

e. Meet and follow developments and changes in international standards as reflected in the 40 FATF Recommendations along with the applicable anti-money laundering regime provisions at the international level (international best practice).

In the application of this Law on Money Laundering, two concepts are emphasized related to punishment in money laundering cases, namely:

1) Context of punishment (by maximizing criminal threats to perpetrators, both corporate and ownership);

2) The context of tracing confiscation to the recovery of assets obtained by perpetrators through unlawful acts.

However, in law enforcement practice, many law enforcers are found who believe that the application of money laundering offenses is considered necessary if it is intended to maximize criminal threats. This causes when the punishment is maximum, the application of the Money Laundering Law is no longer a necessity. On the other hand, some believe that if there are significant assets that can be confiscated and lead to the confiscation of these assets, the Law on Money Laundering is no longer urgent to be implemented. ${ }^{11}$ Although basically, the confiscation of assets is quite large, it is not optimal if a search is carried out on the assets owned, based on the Money Laundering Act. This problem is because the range of legal instruments based on the money-based approach in the Money Laundering of Law is more comprehensive than instruments in other criminal laws in tracing and finding assets.

As previously explained, the formation of the Anti-Money Laundering Law should not only be intended for the benefit of asset withdrawal but rather to maximize criminal threats against criminals related to corruption and money laundering cases. This perspective on the implementation of the Money Laundering of Law will certainly 'minimize' aspects of corporal punishment and

9 Saputra, A. "Babak Baru Sengketa Aset Koperasi Pandawa Rp 3,3 Triliun, Detiknews. 2019, https://news.detik.com/berita/d4534163/babak-baru-sengketa-aset-koperasi-pandawa-rp-33-triliun, accessed on Oct, $10^{\text {th }}, 2020$.

10 Direktorat Hukum PPATK, Modul Workshop Terpadu Penanganan Tindak Pidana Pencucian Uang, Jakarta: PPATK, 2015, p. 65-66.

11 M.G. Novrizal Fernandez, "Penyidik Belum Maksimalkan UU TPPU Untuk Sita Aset Koruptor”, Website : https://kabar24.bisnis.com/read/20180114/16/726258/penyidik-belum-maksimalkan-uu-tppu-untuk-sita-aset-koruptor, accessed on Oct, $10^{\text {th }}, 2020$. 
fines that can be imposed through the Money Laundering of Law, and even lead to a change in direction towards the direction of reforming criminal law policies (penal policy) as referred to in the formation of Law Number 8 of 2010. Apart from the direction of reforming criminal law policies, based on the formation of Law Number 8 of 2010, it is also related to the regulation of efforts to prevent criminal acts and how investigations, prosecutions, trials, and criminal acts are carried out (as an integral part of the Penal Policy). This is oriented not only to the withdrawal of assets resulting from the crime of corruption but rather to convict the perpetrators through the use of the tools of Law Number 8 of 2010 concerning the Prevention and Eradication of the Crime of Money Laundering.

Concerning punishment for money laundering, ideally, if the maximum criminal penalty for a predicate offense is not yet a maximum of a determinate prison sentence (i.e., 20 years), then the application of the money laundering offense becomes very important to be applied in order to maximize the criminal threat to the perpetrator, as long as his actions meet the elements of a money laundering offense. The implementation can be in the form of:

(a) the dossier of the predicate crime case is immediately combined with the money laundering crime; or

(b) the predicate crime case is decided first, and then the money laundering crime is processed, and the money laundering decision adds and completes the crime/punishment for the predicate crime.

Of all criminal acts which constitute the predicate offense of the Crime of Money Laundering, predicate offenses that are punishable by imprisonment of more than 15 years are criminal acts of corruption, narcotics, and terrorism. Even though the threat of imprisonment for the offense is maximum (maximum 20 years), to maximize asset recovery and in the context of sentencing, the application of the crime of money laundering is significant to implement.

In-Law Number 8 of 2010 concerning the Prevention and Eradication of the Crime of Money Laundering, there are 2 (two) variables related to the application of the law on the offense of Money Laundering:

1. Criminal threat;

2. Tools related to asset recovery.

Concerning the implementation of the two variables, there are at least 4 (four) sanctions threat variables as follows:

a. The greatest criminal threat for predicate crimes has not been maximized. Asset tracking has not been maximized.

b. Maximum criminal threats for predicate crimes are maximum. Asset tracking has not been maximized.

c. The greatest criminal threat for predicate crimes is not maximized. Asset tracing is maximum.

d. The greatest criminal threat for top predicate offenses, maximum asset tracing.

Based on these variables, information was collected by asking for opinions and looking at the responses of law enforcers (in this case, judges, public prosecutors, and investigators) and legal academics, as respondents as data from the results of the DITTIPIDEKSUS BARESKRIM FGD study, with 25 respondents who are described in the following table:

Table 1. Mapping of Respondents' Answers

\begin{tabular}{|c|c|c|c|c|c|c|}
\hline \multirow{2}{*}{ Number } & \multirow{2}{*}{ Statement } & \multicolumn{5}{|c|}{ Frequency of Respondents } \\
\hline & & 1 & 2 & 3 & 4 & 5 \\
\hline 1 & $\begin{array}{l}\text { The application of the criminal offense of money laundering for } \\
\text { predicate offenses carries a maximum penalty of } 15 \text { years and above. }\end{array}$ & - & 12 & - & 13 & - \\
\hline 2 & $\begin{array}{l}\text { The application of the criminal offense of money laundering for } \\
\text { predicate offenses with a maximum criminal penalty of fewer than } 15 \\
\text { years. }\end{array}$ & 19 & 6 & - & - & - \\
\hline 3 & $\begin{array}{l}\text { The application of money laundering offenses in the context of } \\
\text { applying the tools permitted by the Money Laundering Law for asset } \\
\text { tracing and asset recovery for the proceeds of crimes } \\
\text { confiscated/confiscated is already extensive (in APH's interpretation). }\end{array}$ & 8 & 9 & - & 8 & - \\
\hline 4 & $\begin{array}{l}\text { The application of money laundering offenses in the context of } \\
\text { applying the tools permitted by the Money Laundering Law for asset } \\
\text { tracing and asset recovery for the proceeds of crimes } \\
\text { confiscated/confiscated has not been maximized. }\end{array}$ & 22 & 3 & - & - & - \\
\hline
\end{tabular}

Explanation:
1: Very important
4: Not important
2: Importance
5: No need
3: not too important 

Related in the Account of Overseas Bank

Based on these primary data, the normative character of legal science, asui generis, cannot be eliminated, where the primary data is used as a compliment and comparison of the normative character of legal science, which is conceptual-theoretical and normative-juridical.

\section{The Law Enforcement in The Monetary Sector in Indonesia Through a Criminal Approach, and Asset Recovery in The} Money Laundering Case

In order to maximize sentencing and asset recovery in the application of money laundering offenses, a paradigmatic construction is needed for law enforcers to criminalize, namely by:

1) Money laundering is a follow-up crime.

2) Partial part of the evidence, where money laundering offenses can be declared as an Independent Crime as stated in Article 69 of the Money Laundering Law. In the application of Article 69 of the Law on the Crime of Money Laundering, the relevant context is if a non-material legal process is carried out against the predicate crime involved in the Crime of Money Laundering. If the material for the predicate crime is unknown or its whereabouts are not found (for example, the status of a DPO), or if the legal process is between the two (Material Dadar for a Crime (TP) of Origin and a non-material Dadar for TP of Original), where each of them is involved in the occurrence of a money laundering offense. ) is done by splitting at almost the same time.

3) Maximize the asset recovery process if the presence and identification of Passive Perpetrators as parties enjoying the proceeds of crime. On the other hand, criminal proceedings can be carried out against passive perpetrators by criminalizing passive perpetrators, even though the original crime has not been proven beforehand.

In the context of asset recovery against the application of money laundering offenses, it is necessary to search for assets that can later be recovered using the tools or instruments contained in the anti-money laundering regime. The instruments used include, among others, requesting information on analysis results from PPATK, blocking of assets, requesting information on assets to the Reporting Party, reversing the burden of proof, to confiscation of additional assets, all of which are only contained in the anti-money laundering regime that can be applied if the offense of laundering money is suspected or charged with the suspect/accused. The Indonesian Financial Transaction Reports and Analysis Centre or INTRAC (Indonesian: Pusat Pelaporan dan Analisis Transaksi Keuangan) or PPATK is a government agency of Indonesia responsible for financial intelligence.

Asset Recovery is significant using instruments to maximize traceable assets, which can then be confiscated, confiscated, and recovered.

\section{CONCLUSIONS}

Based on the above discussion, the existence of a follow the money approach that is more sophisticated than other criminal laws, in the provisions of the Money Laundering Law, is one of the main elements that make the application of money laundering offenses essential to apply, which can be applied if there are allegations or allegations of money laundering offenses - done by the perpetrator. This approach can be used in tracing the extent to which the asset flows.

The use of two perspectives in the withdrawal of assets from the proceeds of Money Laundering is still possible for: (1) assets (either against the proceeds of a crime or the assets of the perpetrator) in the amount of the loss on the proceeds; and (2) all assets (both the proceeds of a criminal act and the assets of the perpetrator) obtained by him, either partially or wholly, derived from the proceeds of a criminal act. These two perspectives each have their own conceptual and juridical basis. That is, each of these perspectives becomes a choice of law for law enforcement, as long as it has not been confirmed and promulgated in the regulation regarding Asset Confiscation. Provisions that may be used as an instrument to maximize asset recovery in the Money Laundering Law have been determined to be used by law enforcement in a fair, proportionate, and appropriate manner for the instrument's designation in order to maximize the value of assets that can be secured for the benefit of asset recovery.

\section{REFERENCES}

\section{Book}

1) Farid, Zainal Abidin. 2007. Hukum Pidana 1. Jakarta: Sinar Grafika.

2) Financial and Development Audit Agency (BPKP). 2000. Strategi Pemberantasan Korupsi Nasional. March edition.

3) Effendi, Erdianto. 2011. Hukum Pidana Indonesia-Suatu Pengantar. Bandung: PT Refika Aditama.

4) Edi Setiadi dan Rena Yulia. 2010. Hukum Pidana Ekonomi. Yogyakarta: Graha Ilmu.

5) Harkrisnowo, Harkristuti. 2003. Kriminalisasi Pemutihan Uang: Tinjauan Terhadap UU No.15 tahun 2002, ProceedingsKerjasama Pusat kajian Hukum dan Mahkamah Agung RI, cet.I. Jakarta: Mahkamah Agung RI.

6) Hoefnagels, G.P. 1972. The Other Side of Criminology. Kluwer- Deventer, Holand.

7) Husein, Yunus. 2007. Bunga Rampai Anti Pencucian Uang, Bandung: Books Terrace \& Library.

8) Muladi and Arief, Barda Nawawi. 2005. Teori-Teori dan Kebijakan Hukum Pidana. Bandung: Alumni.

9) Muladi and Nawawi, Barda. 1992. Teori dan Kebijakan Pidana. Bandung: Alumni. 
Assets Recovery of Money Laundering Criminal Acts: A Study of Restoring Assets for Money Launching Criminal Acts Related in the Account of Overseas Bank

10) Nilsson, Hans G. 1996. Preface, in Paolo Bernasconi (ED), Money Laundering and Banking Secrecy, General Report of Xi Vth International Congress of Comparative Law. Athens.

11) Prakoso, Djoko. 1988. Surat Dakwaan, Tuntutan Pidana dan Eksaminasi Perkara di Dalam Proses Pidana. Yogyakarta: Liberty.

\section{Legislation}

1) Indonesia, 1945, Constitution of the Republic of Indonesia

2) Indonesia, 2010, Law of the Republic of Indonesia Number 8 of 2010 concerning prevention of the Crime of Money Laundering.

\section{Journals and Thesis}

1) Amrullah, M. Arief, "Tindak Pidana Pencucian Uang (Pengantar Pemahaman Awal Bagi Peserta Pendidikan Kurator)", papers submitted to Curator and Management Education, organized by Himpunan Kurator dan Pengurus Indonesia (HKPI), Jakarta: Alberto Ballroom, Belleza Suite, May, 28 $8^{\text {th }}, 2016$

2) Bahreisy, Budi, "Implementasi Undang-Undang Tindak Pidana Pencucian Uang Terhadap Kerugian Negara Dari Tindak Pidana Korupsi”, Jurnal Legislasi Indonesia, Vol 15 No.2, July 2018, Medan: Universitas Dharmawangsa Medan.

3) Dittipideksus, "Kajian Hukum: Penerapan Delik Pencucian Uang Untuk Tujuan Pemidanaan Dan Asset Recovery", Jakarta: Bareskrim, November 2019.

\section{Website}

1) M.G. Novrizal Fernandez, "Penyidik Belum Maksimalkan UU TPPU Untuk Sita Aset Koruptor”, https://kabar24.bisnis.com/read/20180114/16/726258/penyidik-belum-maksimalkan-uu-tppu-untuk-sita-aset-koruptor.

2) Billy Steel, "Money Loundering - What is Money laundering," http/www.laundryman.u-net.com.

3) Saputra, A. "Babak Baru Sengketa Aset Koperasi Pandawa Rp 3,3 Triliun”, https://news.detik.com/berita/d4534163/babak-baru-sengketa-aset-koperasi-pandawa-rp-33-triliun. 